\title{
Implementation of Project-based Learning Innovation to Develop Students' Critical Thinking Skills as a Strategy to Achieve Analytical Chemistry Competencies
}

\author{
Manihar Situmorang ${ }^{1, *}$, Marudut Sinaga ${ }^{2}$, Marham Sitorus' ${ }^{1}$, Ajat Sudrajat ${ }^{2}$ \\ ${ }^{1}$ Department of Chemistry, Faculty of Mathematics and Natural Sciences, Universitas Negeri Medan, Medan, \\ North Sumatera, INDONESIA. \\ ${ }^{2}$ Chemistry Education, Graduate Study Program (Program Pascasarjana), Universitas Negeri Medan, Medan, \\ North Sumatera, INDONESIA.
}

\begin{abstract}
Background: The ability to think critically is one of the life skill targets that pharmacists and scientists want to achieve in learning, therefore it is necessary to do project-based learning innovations to guide students to learn actively and independently in developing critical thinking skills. Objectives: This study aims to implement project-based learning to facilitate active and independent learning through project implementation to build students' critical thinking skills and at the same time to facilitate students to achieve competencies in the analytical chemistry required by pharmaceutical and chemical scientists. Materials and Methods: Research includes the development of project packages and the integration of information technology on the topic of Distillation, standardization of learning resources, and implementation of Analytical Chemistry teaching. Results: An innovative project-based learning resource package was successfully developed for the Distillation topic. Implementation of learning resource packages effectively guides students to carry out their own projects in separating target compound contextually through distillation method. The learning facilities available in the learning package have proven to be able in guiding students to design project assignments suit to target analyte. The learning potential of students has been optimized. Students' knowledge and skills in separating target analytes by distillation have been fully mastered as desired in the competency-based curriculum. The results of the assessment showed that the students' critical thinking skills were very good $(\mathrm{M}=84.51 \pm 7.41)$. Student learning outcomes based on the portfolio value of the project proposal ( $\mathrm{M}=88.46 \pm 6.74)$ and project reports ( $\mathrm{M}=92.85 \pm 1.98$ ), and from the objective score of the formative exam ( $M=85.59 \pm 3.09$ ) are all classified very good, namely the competence in the analytical field is achieved. Conclusion: Project-based learning innovations are very effective in improving critical thinking skills as well as increasing student competence in the field of analytical chemistry. Recommendation: Project-based learning is suitable for implementation in teaching other subjects to achieve the competencies required by scientists. This learning model is effective in building student competence in a normal learning atmosphere, or when social restrictions are imposed during the COVID-19 pandemic.

Key words: Project-based learning, Learning innovation, Critical thinking skills, Students competence, Learning outcomes.
\end{abstract}

Submission Date: 04-05-2021; Revision Date: 23-10-2021; Accepted Date: 29-12-2021

DOI: 10.5530/ijper.56.1s.41 Correspondence:

Prof. Dr. Manihar Situmorang, M.Sc Department of Chemistry, Faculty of Mathematics and Natural Sciences, Universitas Negeri Medan, Jl. Willem Iskandar, Psr V Medan Estate, Medan-20221, North Sumatera, INDONESIA E-mail: msitumorang@ unimed.ac.id

\section{INTRODUCTION}

Critical thinking skill (CTS) is very necessary in learning science and related to life skills for students, pharmacists and chemists. ${ }^{1}$ The CTS is a scientific skill to construct the lead students to a deep understanding of knowledge from the available information and analyzing them for use in solving problems and drawing conclusions which

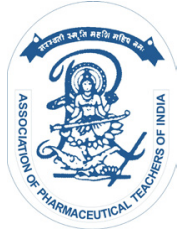

www.ijper.org 
the subject being studied. The CTS is very appropriate to be applied in all aspects of learning because they are associated with increasing learning activities, especially in teaching of pharmacy and chemistry. ${ }^{2}$ The strategies to improve critical thinking skills must be carried out because the work associated with science bound the scientific activities such as data collection, analysis, interpretation and conclusion. ${ }^{3,4}$ Learning innovation that adapts to the latest technology is a good strategy in improving critical thinking skills, because it can facilitate students to learn actively and optimally in achieving the targets competency stated in the curriculum. ${ }^{5,6}$ The implementation of competence curriculum has brought a change in the target competence for the subject learned at university level, including pharmacy and chemistry. ${ }^{7}$ With this curriculum, learning must be equalized and juxtaposed with the need for skills needed to work in relevant fields. The subject studied in university must be relevant to the needs of expertise in employment after completing the study program. Therefore, learning materials must be packaged in an attractive manner to equip students contextually to understand the theories and skills needed by industry or other jobs in the pharmaceutical and chemical fields. ${ }^{8}$ The problem is the tendency of learning which is dominated by theory and minimal skills in the field of analytical chemistry, which is caused by restrictions on practicum activities in laboratories as a result of social restriction policies during the COVID-19 pandemic to break the chain of virus transmission. ${ }^{9}$ In addition, learning tends to lead students to formulas that cause them to get used to memorizing topics without knowing the usefulness of the material being studied. This problem must be overcome through the application of innovative projectbased learning to build critical thinking skills that can encourage the internalization of theory and practice in real practice through project implementation.

The Separation course in Analytical Chemistry is very much needed by scientists because it deals with the technique of separating the target analyte from its mixture for enrichment, concentration, refining, isolation, purification and determination purposes. ${ }^{10}$ The technique is very important to provide a basic knowledge on the strategy of separating the target compound from the mixture before quantitative determination can be carried out appropriately. Analytical separation is also intended to purify the target compound to become high grade substances. Analytical chemistry textbooks generally have special chapters on separation procedures starting from simple technique by using low cost apparatus to complex procedures with involving of sophisticated instrumentations. ${ }^{11-13}$ One of the separation procedures that are used in analytical chemistry is distillation method. Separation by distillation is very important in the undergraduate pharmacy and chemistry curriculum since a technique is widely applied for the separation of organic compounds of binary mixture. ${ }^{14}$ The strategy is used to remove the contaminants from the desire substance into a pure substance. The distillation method is carried out by approaching or manipulating of the boiling point differences followed by the condensation process to make one compound can be separated from the mixture. Various distillation techniques can be applied to separate the substances depending on the nature and characteristics of the target compounds. Distillation procedures that are commonly applied in analytical separation namely simple distillation, fractional distillation, steam distillation, vacuum distillation and molecular distillation. Those separation techniques are necessary to be mastered by the students to provide adequate knowledge and skills in analytical separation chemistry. ${ }^{15,16}$

Various strategies have been carried out in the teaching of analytical chemistry to make learning more interesting, easy to remember and bring students to the real world. ${ }^{17,18}$ Some of these include the selection of good teaching and learning strategies, the application of innovative learning, the use of media and multimedia, learning based on blended learning and e-learning, the application of new learning models, and other learning methods. ${ }^{19-22}$ One of the strategies used to optimize students' learning independence is to utilize innovative learning resources that are obtained through project-based learning innovations. ${ }^{23}$ A project-based learning $(\mathrm{PjBL})$ is designed to carry out investigations through complete research activities. This learning model provide opportunities for students to do scientific discoveries systematically through critical thinking. Project-based learning can be carried out through laboratory experiments, field studies and work assignments, which in turn to increase the scientific knowledge and skills. ${ }^{24-26}$ The project-based learning process is carried out on a regular basis starting from setting of the targets competency to be achieved, planning of the project, designing and establishing the project activity procedures, project implementation, and reporting the results and findings. Through the project, the students have adequate time to apply critical thinking skills to build their knowledge and skills in the field of chemistry. ${ }^{27}$ The freedom in using available learning resources is also becomes a credit when doing the project in order to achieve the desired competencies. Projectbased learning has been used successfully to increase the knowledge and skills in various fields of science, including teaching of chemistry, and is believed to be 
very effective for teaching of Analytical chemistry. ${ }^{28,29}$ The purpose of this research is to innovate a projectbased learning package that will be used as a learning resource to build students' critical thinking skills through the implementation of research projects as a strategy to achieve competency targets in the field of analytical separation required by scientists such as pharmacists and chemists. The project-based learning will be able in facilitating active and independent learning to build students' knowledge and skills in the field of Analytic chemistry.

\section{MATERIALS AND METHODS}

\section{Population and Sample}

The research was conducted at the Department of Chemistry, Faculty of Mathematics and Natural Sciences (FMIPA), Universitas Negeri Medan in the 2020/2021 academic year. The work involved 73 students from three parallel classes selected from the Chemistry Education Study Program at the faculty.

\section{Research Ethics}

To comply with the research code of ethics established by the university, students are notified that they have been included as research objects. Students are given the freedom to participate as research samples by following ethical social science research protocols. Research respondents were given statements and explanations about the terms and procedures that had been established through the rules of the Human Research Ethics Committee of the Universitas Negeri Medan. In this case, all students are willing to be used as research objects for the implementation of projectbased learning.

\section{Research Methods}

This research is the development of project-based innovative learning resources based on the need for the achievement of analytical chemistry competencies for students according to the demands of a competencybased curriculum. Data collection was carried out with a mixed exploratory method design, namely through a survey to collect respondents' opinions which were then converted into quantitative data (Likert scale), and quantitative data in the form of student learning outcomes obtained from a portfolio of project activities and learning evaluation scores. ${ }^{30,31}$

\section{Research Procedures}

The research was carried out in several stages, starting from the needs analysis stage for Analytical Chemistry courses, developing innovative project-based learning

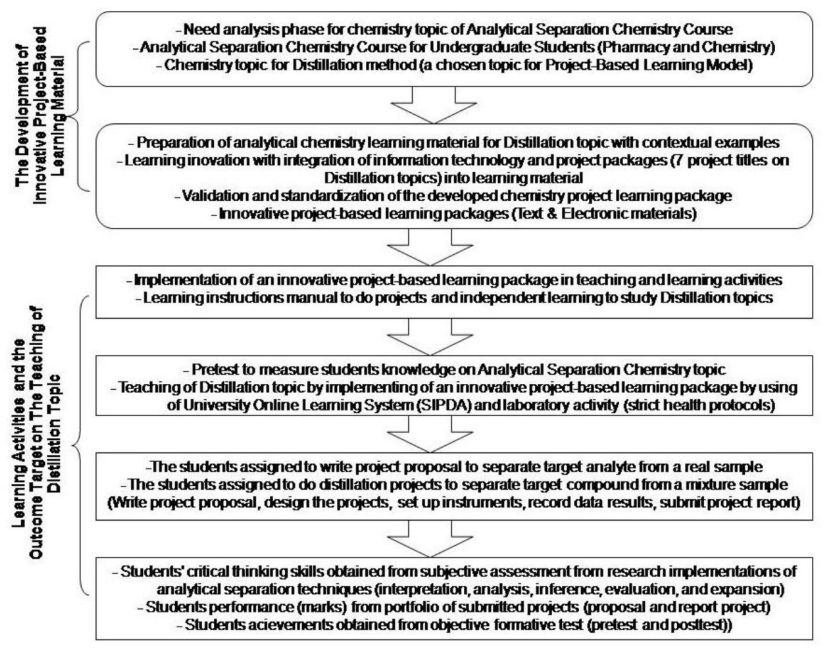

Figure 1: The summary of research procedures for the development and implementation of project-based learning in the teaching of distillation topic on Analytical Separation Chemistry.

packages for the topic of Distillation (as a development model), and implementing innovative learning packages in Analytical Chemistry teaching. The provision of research instruments was also carried out, including project implementation guidelines, a survey package to assess the feasibility of innovative learning resources, an assessment rubric of project proposals and project implementation reports, and evaluation tests to measure learning outcomes. The research procedure is illustrated in Figure 1. Needs analysis for chemical materials is carried out by proposing several relevant sub-topics for the Analytical Separation course. Chemistry topics are then given to expert lecturers to assess their suitability with the competency targets to be achieved by scientists working as pharmacists and chemists. Distillation topic was then chosen in this study as a learning model to be developed into an innovative project-based teaching materials for students at university level.

\section{Development and Standardization of Innovative Project-Based Learning for Distillation Topic}

The development of project-based innovative learning packages is carried out by enriching the teaching material with complete theories for each subject matter, and equipped with contextual examples of the application of distillation in everyday life. Chemistry learning materials are then integrated with project examples, multimedia and videos, and linking the Distillation topic with hyperlinks to trusted websites with the intention of making the topic easy to learn. Standardization of teaching materials is then carried out using experts, namely lecturers who are experienced in teaching Analytical Chemistry for at least three consecutive years, 
to ensure that the quality of the teaching materials has been achieved. The assessment of teaching materials is carried out following the criteria provided by the Indonesian National Education Standards Board (Badan Standar Nasional Pendidikan, BSNP). Learning resource packages along with project implementation instructions are provided in print and electronic versions as a medium for studying the topic of Distillation.

\section{Preparation of Research Instruments}

Research instruments were provided and standardized, consisting of a standardized questionnaire to assess the suitability of chemical topics and to assess the quality of teaching materials (Likert scale 1-4), subjective assessment rubrics measuring critical thinking skills and assessing projects for Proposals and project reports (marking scale 0-100), and multiple choice evaluation tests to measure student learning outcomes (evaluation scores converted to marks 0-100). Standard questionnaire packages are arranged in accordance with the objectives of the study, and then validated using experts and followed by trials to see the validity of the components of the questions in the questionnaire. The same procedure is carried out to provide chemical questions (items) that cover the subject of Distillation.

\section{Implementation of Project-Based Learning in the Class}

Complying with government policies during the COVID-19 Pandemic, social restrictions apply to the learning system at the University in order to break the chain of spread of the corona virus-19. Learning in this study was conducted online using the University Online Learning System (Sistem Pembelajaran Daring Universitas Negeri Medan, SIPDA) combined with teaching using a zoom meeting. Project implementation is limited and selective in the laboratory following strict health protocols. Pretest is done before learning begins to determine students' mastery of Analytical Chemistry course. The students informed about course descriptions, competencies to be achieved in learning, chemical materials to be studied, and project assignments that will be carried out in teaching and learning activities. The main stage is the implementation of project-based learning for teaching the topic of Distillation. The stages of learning carried out by students are compiling their own project plans through the preparation of proposals uploaded to SIPDA. Project implementation is carried out after obtaining approval from the lecturer and project work is always under the supervision of the instructor. All project-based learning carried out in the laboratory always follows health protocols consistently in accordance with regulations set by the university. The results of the investigation are reported in the form of a project report uploaded to SIPDA. The evaluation test is carried out at the end of the lesson.

The students were obliged to do two sets of distillation projects in the given time allocation, and the project reports had to be submitted one week after completing the works. Teaching and learning activities in project implementation are observed, project reports are assessed, and students' mastery of the topics studied is evaluated at the end of the lesson. Students' critical thinking skills are assessed from student's ability in the interpretation, analysis, inference, evaluation, and expansion. The marks from submitted project reports were counted followed the judgment criteria for submitted projects. The marking criteria for the projects were based on the structure design of the project planning (Project proposal), laboratory activities, product yield recovery, and report presentations. Formative test was conducted after completing of the teaching and learning activities in the teaching of Distillation topic. The score obtained from evaluation test was counted from the right answers of multiple choice test without giving the penalty for wrong answers. Student learning outcomes are recorded from the combination of the scores obtained in the project report portfolio with the scores obtained in the evaluation on the formative exam. The data is presented in the form of learning outcomes, namely students' critical thinking skills and student learning outcomes. Student learning completeness is expressed in the form of competency attainment based on the cumulative learning outcomes.

\section{RESULTS}

\section{Analytic Separation Chemistry Course}

Analytical Separation Chemistry course is an advanced course for university students. It is the course that brings students to master separation technique as a competency required for pharmacists and chemists. The course aims to build knowledge and skills on separation techniques for the purposes of isolation, purification and quantitative determination. Separation chemistry provides the skill to separate chemical compounds by using analytical equipment's. The study to select the topic for Analytical Separation Chemistry course has been carried out, that is by choosing and analyzing the chemistry contents available in various textbooks that are relevant for analytical separation at university level. The course has a value of four credit points and is programmed for 16 meetings in one semester. One credit point is allocated to be equivalent 
to $50 \mathrm{~min}$ of lecture time and $120 \mathrm{~min}$ of structured learning and independent study. List of the chemistry topic of Analytical Chemistry Separation course, and respondents' assessments given by the lecturers are summarized in Table 1. The chemistry lecturers strongly agreed (average 3.78 \pm 0.43 ) to the proposed chemistry topic that were chosen to be included in an Analytical Separation Chemistry course. Innovative project-based learning for the topic Distillation is discussed in detail as an example of project implementation in the teaching of analytical chemistry.

\section{Project-based Learning Package for Distillation Topic}

A complete and in-depth chemistry teaching material has been compiled for the subject of Distillation. The subject is enriched with the theory of separation using temperature differences which is equipped with contextual examples of the analysis of the separation of chemical compounds of medicinal raw materials. Each subject is equipped with examples of relevant innovative project packages and accompanied by project implementation video media to guide students in carrying out their own projects in separating the target compounds by distillation correctly. A teaching material has been arranged systematically based on the needs of science students in accordance with the competency targets that will be achieved after completing the learning. The Distillation topic has been arranged in to five Sub-topics, they are: (1) Introduction to Separation by Distillation Method, (2) Principle of Distillation (Raoult's Law and Dalton's Law), (3) Types of Distillation, (4) The Azeotrope, and (5) Application of Distillation Method. The description of leaning innovation and the projects that have been developed as supplement material into the chemistry learning package are summarized in Table 2 . The chemistry material for each of the sub-topics has been enriched suited to the needs of undergraduate chemistry students as required by the chemistry competence curriculum. Furthermore, innovations in the teaching materials are carried out to bring the analytical chemistry topics are easily studied by the students and gives the impression of learning that is long remembered. Learning innovation is performed based on the characteristics of the sub-topics, and is also adapted to the latest technological advancements with consideration to the availability of chemistry equipment's, chemicals reagents, and supporting facilities. The project packages have been integrated into learning materials along with video sets examples of project implementation are also included into the teaching materials to make it easy for students to study
Table 1: List of chemistry topics of Analytical Separation Chemistry course, the allocation time to complete the topic, and respondents' opinions to the proposed listed topics.

\begin{tabular}{|c|c|c|c|}
\hline No & Chemistry Topic & $\begin{array}{c}\text { Allocated } \\
\text { Time } \\
\text { (weeks) }\end{array}$ & $\begin{array}{c}\text { Respondents } \\
\text { opinion }(\mathbf{n}=\mathbf{8})^{*}\end{array}$ \\
\hline 1 & $\begin{array}{c}\text { Introduction to analytical } \\
\text { separation chemistry }\end{array}$ & 1 & $3.63 \pm 0.52$ \\
\hline 2 & Distillation method & 3 & $3.75 \pm 0.46$ \\
\hline 3 & Extraction method & 2 & $3.88 \pm 0.35$ \\
\hline 4 & $\begin{array}{c}\text { Deposition and electrode } \\
\text { position methods }\end{array}$ & 1 & $3.63 \pm 0.52$ \\
\hline 5 & $\begin{array}{c}\text { Centrifuge method for } \\
\text { analytical separation }\end{array}$ & 1 & $3.75 \pm 0.46$ \\
\hline 6 & Basic Chromatography & 1 & $3.88 \pm 0.35$ \\
\hline 7 & Gas Chromatography & 2 & $3.88 \pm 0.35$ \\
\hline 8 & Liquid Chromatography & 3 & $3.88 \pm 0.35$ \\
\hline 9 & Basic Electrophoresis & 1 & $3.63 \pm .046$ \\
\hline 10 & Capillary electrophoresis & 1 & $3.75 \pm 0.52$ \\
\hline & Total / Average & 16 & $3.78 \pm 0.43$ \\
\hline
\end{tabular}

*The marking criteria: $4=$ very agree; 3 = agree; 2 = relatively agree, and $1=$ disagree.

the subjects and to construct their own projects as assigned in the learning stages.

\section{Standardization Results for Project-Based Learning Package}

An innovative Project-based learning material for Distillation topic has firstly been validated to meet the criteria as learning resource for undergraduate science students in tertiary institutions. Validation and standardization results from experienced lecturers have been received for their comments to the content and feasibility of the developed learning material as summarized in Table 3. The content of the chemistry material has been assessed for its feasibility as a learning resource that can guide students to study chemistry and complete the analytical separation chemistry project assignments to improve their competence. The validation results show that the project-based learning material has met the requirements seen from the depth of the content, the availability of learning tools, the suitability of the project package, and the relevance of integrated learning package. The use of language in the learning material and the design of the package also meet the requirements criteria given by BSNP. The assessments results obtained from expert respondents were very good (an average of $3.71 \pm 0.49$ ). The developed material was confirmed to be suitable 


\begin{tabular}{|c|c|c|c|}
\hline No & Sub-topic & Description of innovation into chemistry learning material & Project Integration \\
\hline 1 & $\begin{array}{l}\text { Introduction to } \\
\text { Separation by } \\
\text { Distillation Method }\end{array}$ & $\begin{array}{l}\text { The Distillation topic is enriched with the chemistry materials on the } \\
\text { introduction to Separation by Distillation Method. In this section, the } \\
\text { introduction to Distillation method that has been used in daily life is } \\
\text { explored. To explain the introduction to Separation by Distillation method } \\
\text { was done with the integration of learning media, pictures, and illustrations } \\
\text { into chemistry topic. The learning media of video and the example of } \\
\text { distillation separation are provided }\end{array}$ & $\begin{array}{l}\text { Project 1: Separation by } \\
\text { Simple Distillation }\end{array}$ \\
\hline 2 & $\begin{array}{l}\text { Principle of Distillation } \\
\text { (Raoult's Law and } \\
\text { Dalton's Law) }\end{array}$ & $\begin{array}{l}\text { Enriching a topic of principle distillation and the explanation for equilibrium } \\
\text { between liquid phase and gas phase with mass transfer of the component } \\
\text { follow the Raoult's Law and Dalton's Law are provided. The projects is } \\
\text { used to demonstrate the relationship boiling point and the vapor pressure } \\
\text { of a mixture of compounds of Binery mixture. The project for the mixture of } \\
\text { two miscible liquids based on Dalton's Law are also included. }\end{array}$ & $\begin{array}{l}\text { Projects 2: Separation } \\
\text { of components by using } \\
\text { Fractional Distillation }\end{array}$ \\
\hline 3 & Types of Distillation & $\begin{array}{l}\text { The chemistry materials for types of distillation topic was enriched. Those } \\
\text { are including (1) Simple Distillation, (2) Fractional Distillation, (3) Steam } \\
\text { Distillation, (4) Vacuum Distillation, and (5) Molecular Distillation. The } \\
\text { learning media and videos to demonstrate various type of distillations and } \\
\text { how to set the distillation equipment are provided. The projects to make the } \\
\text { students understand various type of distillation topics are provided. The } \\
\text { diagram phase of fractional distillation for calculating the theoretical plate } \\
\text { is demonstrated. }\end{array}$ & $\begin{array}{l}\text { Projects } 3 \text { and } 4 \text { : } \\
\text { Separation of Bioactive } \\
\text { compounds from leaves } \\
\text { of medicinal plants by } \\
\text { using Steam Distillation }\end{array}$ \\
\hline 4 & The Azeotrope & $\begin{array}{l}\text { The topic on Azeotrope compounds and its properties are integrated, and } \\
\text { the project packages to demonstrate Azeotrope compounds are provided } \\
\text { in the learning material. The video of experimental works on Azeotrope } \\
\text { compounds, type of Azeotrope and the principle separation by using } \\
\text { Boiling-Point Azeotrope are integrated in the learning package. Handling } \\
\text { of experiment such as vacuum distillation and molecular distillation are } \\
\text { provided in the learning media. }\end{array}$ & $\begin{array}{l}\text { Projects 5: Purification of } \\
\text { Alcohols by using Steam } \\
\text { distillation }\end{array}$ \\
\hline 5 & $\begin{array}{c}\text { Application of } \\
\text { Distillation Method. }\end{array}$ & $\begin{array}{l}\text { The project examples on the applications of Distillation methods to } \\
\text { separate real samples are provided into a learning package as videos and } \\
\text { multimedia formats. Separation of Eugenol from clove leaves in the form of } \\
\text { video are integrated in teaching material. }\end{array}$ & $\begin{array}{l}\text { Projects 6: Production of } \\
\text { essential oils from plants } \\
\text { leaves }\end{array}$ \\
\hline
\end{tabular}

\begin{tabular}{|c|c|c|}
\hline No & The validation criteria for the developed project-based teaching material & $\begin{array}{l}\text { Respondents opinion } \\
(M \pm S D), L(n=8)^{*}\end{array}$ \\
\hline 1 & $\begin{array}{l}\text { - The Content: the completeness and the accuracy of chemistry contents in the learning material } \\
\text { that are suited to the need of undergraduate science students. }\end{array}$ & $3.75 \pm 0.46$ \\
\hline 2 & $\begin{array}{l}\text { - The Extension: Integration of the project packages, video and multimedia, and learning facilities } \\
\text { in the learning package, }\end{array}$ & $3.69 \pm 0.49$ \\
\hline 3 & $\begin{array}{l}\text { - The Depth: The depth and relevance of the project-bases package to the chemistry topic and the } \\
\text { chemistry topic has been presented in good order containing of: introduction, the main concepts, } \\
\text { problem examples, project-based, drills, quiz, and the hyperlinks to trustworthy websites, and the } \\
\text { application for real life }\end{array}$ & $3.69 \pm 0.46$ \\
\hline 4 & $\begin{array}{l}\text { - The Design: The layout of learning material are suitable, the presentation, illustrations, Figures, } \\
\text { table, images are adequate for independent learning }\end{array}$ & $3.79 \pm 0.41$ \\
\hline 5 & $\begin{array}{l}\text { - The Language: The learning materials are easy to read, the language is simple, the message } \\
\text { in accordance with the learner development, scientific messages are straightforward, the typist of } \\
\text { chemical structure, reaction and symbol are accurately presented }\end{array}$ & $3.71 \pm 0.49$ \\
\hline & Average & $3.71 \pm 0.49$ \\
\hline
\end{tabular}

*Marking criteria: 4 = very good $3=$ good 2 = poor, and $1=$ very poor. 
for use as teaching material for teaching of Analytical Separation Chemistry course.

\section{Implementation of innovative project-based learning in the class}

Teaching and learning activities with implementation of project-based learning has been applied in the classroom for the teaching of Distillation topic. The students construct the projects following the procedures provided in the learning package. The project-based learning has been designed to build students' independence to study analytical chemistry and used as a strategy to develop students' critical thinking skills and activate learning potential to achieve the required competence in analytical chemistry. The students have optimized their learning opportunities in doing investigation and discovery through the projects implementation. They are free to design Distillation sets depends on the target sample to be separated in the projects. The students has able to manage the time starting from planning, implementing, and reporting the assigned tasks. The planned projects have been done well and the students can gain skills in analytical procedures, starting from providing analytical solutions, carrying out chemical separation process, choosing the target samples, and handling problems encountered in the project being worked on. The project works have been conducted in good order depending on the sample target, and report the project results on time. Students' critical thinking skills have been developed through project-based learning activities, and the skills acquired by students are summarized in Table 4. Students' thinking skills in all aspects are classified as very good (on average $84.51 \pm 7.41$ ). The students have the skills to arrange instrumentation similar to the examples given in the developed learning package that are suited to the target analyte to be separated. Through project implementation, student's critical thinking skills have developed such as the ability to collect data, analyze data, interpret result data, present findings, and apply them in real life.

The final stage of the research was to measure students' mastery of the topic of distillation, which is known from student learning outcomes as a result of implementing the project-based learning innovation. Students' achievement results (scores) obtained from the mark portfolio of submitted project proposal, projects reports, and evaluation scores of pretest and posttest are summarized in Table 5. The average student learning outcomes are classified as excellent in both, the portfolio value of the project proposal $(\mathrm{M}=88.46 \pm 6.74)$ and the final project report $(M=89.31 \pm 6.73)$. The average score of formative exams is also very good $(\mathrm{M}=87.18 \pm 6.33)$, which is very far compared to the average pretest $(\mathrm{M}=23.63 \pm 4.08)$. It can be stated from these results

\begin{tabular}{|c|c|c|c|}
\hline No & $\begin{array}{c}\text { Aspect of critical } \\
\text { thinking }\end{array}$ & Description of Critical Thinking Skills & $\begin{array}{c}\text { Student's } \\
\text { achievement* }\end{array}$ \\
\hline 1 & Interpretation & $\begin{array}{l}\text { Have the skills to design the projects for Distillation topic, to choose the right equipment } \\
\text { and target sample for contextual works, understand the information contained in the } \\
\text { data obtained from the observation. }\end{array}$ & $84.72 \pm 7.61$ \\
\hline 2 & Analysis & $\begin{array}{l}\text { Have the skills to do analytical works in their projects related to the given topics, to } \\
\text { prepare reagents and solutions starting from weighing and dissolving chemical } \\
\text { compounds in the solvents, standardizing the reagents, and storing the reagents for } \\
\text { further use in the projects, and select relevant data, process and predict the identified } \\
\text { results and conclude logically with precision. }\end{array}$ & $81.79 \pm 8.69$ \\
\hline 3 & Inference & $\begin{array}{l}\text { Be able to perform the project in correct order, starting from setting up the instruments, } \\
\text { noting and recording results, overcoming trouble shooting in the laboratory, maintaining } \\
\text { safety works, and washing up the glass wares, and identify the meaning of the inferential } \\
\text { relationship between data, questions, and science concepts. }\end{array}$ & $85.38 \pm 6.68$ \\
\hline 4 & Evaluation & $\begin{array}{l}\text { Have the ability to write project reports based on the format given in the learning material, } \\
\text { be able to express their scientific view in the results and discussion in accordance to } \\
\text { the data results and chemical phenomena obtained in the projects, having skills in } \\
\text { presenting their invention and discovery from projects works, and assess data quality } \\
\text { and provide a representative explanation. }\end{array}$ & $87.33 \pm 6.44$ \\
\hline \multirow[t]{2}{*}{5} & Expansion & $\begin{array}{l}\text { Be able to answer the questions given in the innovative } \mathrm{PjBL} \text { learning material related } \\
\text { to the projects that have been completed, and present reasons and justify convincing } \\
\text { arguments based on the quality of the resulting data. }\end{array}$ & $83.31 \pm 7.61$ \\
\hline & & Average & $84.51 \pm 7.41$ \\
\hline
\end{tabular}

* Subjective assessment criteria 0-100. 
Table 5: Students' outcomes obtained from the marking results from portfolio of submitted projects (proposal and report) and the evaluation score (pretest and formative test) on the teaching of Distillation topic.

\begin{tabular}{|c|c|c|c|c|c|c|c|}
\hline \multirow[t]{3}{*}{ No } & \multirow[t]{3}{*}{ Study Program } & \multirow[t]{3}{*}{ Students $(n)$} & \multicolumn{4}{|c|}{ Students' outcomes $(M \pm S d v)$} & \multirow{3}{*}{$\begin{array}{c}\text { Competence } \\
\text { summary }\end{array}$} \\
\hline & & & \multicolumn{2}{|c|}{ Project score* } & \multicolumn{2}{|c|}{ Evaluation score ${ }^{\star *}$} & \\
\hline & & & Proposal & Final Reports & Pretest & Posttest & \\
\hline 1 & Chemistry Education A & 30 & $88.56 \pm 7.34$ & $89.86 \pm 6.46$ & $23.68 \pm 3.04$ & $87.36 \pm 7.04$ & $\begin{array}{l}\text { Competence } \\
\text { achieved }\end{array}$ \\
\hline 2 & Chemistry Education B & 25 & $88.00 \pm 6.24$ & $89.34 \pm 6.46$ & $23.28 \pm 4.79$ & $86.06 \pm 5.15$ & $\begin{array}{l}\text { Competence } \\
\text { achieved }\end{array}$ \\
\hline 3 & $\begin{array}{c}\text { Chemistry Education } \\
\text { Bilingual }\end{array}$ & 18 & $88.83 \pm 6.63$ & $88.72 \pm 7.27$ & $23.94 \pm 4.40$ & $88.11 \pm 6.79$ & $\begin{array}{l}\text { Competence } \\
\text { achieved }\end{array}$ \\
\hline & Average & 73 & $88.46 \pm 6.74$ & $89.31 \pm 6.73$ & $23.63 \pm 4.08$ & $87.18 \pm 6.33$ & $\begin{array}{c}\text { Competence } \\
\text { achieved }\end{array}$ \\
\hline
\end{tabular}

*Average score of the submitted project portfolio for both proposal and final report

**The average value of the evaluation of learning outcomes for the pretest (before lecture) and formative examination (at the end of the learning session)

that competence in the field of separation analysis has been achieved.

\section{DISCUSSION}

Competence in analytical chemistry is very difficult to achieve through learning during the COVID-19 pandemic because of inherent separation skills which are generally obtained through laboratory practice. Blended learning through a combination of online teaching and project implementation is appropriate for distillation separation teaching. The availability of standard project packages that are integrated in the teaching material becomes a medium for teaching students on analytical separation. The developed learning resource package facilitates students to study independently, and guides students to plan separation projects according to target analytics. The PjBL innovations facilitate the students to carry out the project in the laboratory in an allocated time by working to follow health protocols. Through the implementation of the project itself, the students are provided with contextual knowledge as a strategy to build critical thinking skills in the context of achieving competencies on doing research in the field of separation analysis. ${ }^{32,33}$

Project-based learning has been proven to be effective in building critical thinking skills in students in the field of analytic separation. This learning is effective in facilitating active independent learning to achieve competence in the field of separation chemistry. ${ }^{34}$ The learning process takes place optimally. The $\mathrm{PjBL}$ has succeeded in bridging theory and practice as evidenced by the ability of students to select the appropriate type of distillation to separate the target analyte from the sample. ${ }^{35}$ Students are able to design their own projects, carry out distillation projects to separate target analytes. Contextually, the distillation project is carried out well to separate chemical compounds that have high economic value such as medicinal raw materials contained in the sample. The distillation type chosen by the students varied from simple distillation, stratified distillation, and molecular distillation. Project-based learning has built students' critical thinking skills seen from the ability to synthesize their knowledge to distillate the target analyte properly. ${ }^{36,37}$ The portfolio achievement score for project proposals and reports is also in the very good category. The developed $\mathrm{PjBL}$ is optimally able to encourage students to utilize available learning resources for learning activities, such as innovative teaching materials developed, digital libraries, hyperlinks from websites, and laboratory facilities. Several analytical skills have been built in students, including the knowledge of choosing the right type of distillation for the target analyte, providing chemicals and solutions, the ability to assemble and use analytical tools, skills in observing, collecting data, and reporting project results correctly. ${ }^{38,39}$ The project-based learning model has succeeded in getting students accustomed to using technology-based learning resources to plan and carry out their own projects.

Project-based learning has been proven to be able to develop students' critical thinking skills. Students have been directly involved in planning, implementing, and reporting on assigned projects. Students are empowered to master the strategy of separating the target compounds correctly according to the separation theory. ${ }^{40,41}$ The application of innovative PjBL has been able to streamline face-to-face time in the laboratory as a strategy for implementing appropriate learning during the current COVID-19 pandemic. $^{42}$ This learning is 
very effective in increasing knowledge and skills of separation techniques, and facilitating students to achieve their competence in analytic separation. ${ }^{43}$ The $\mathrm{PjBL}$ model is ideal for learning science, because theory can be realized by practice contextually resulting in a long-remembered impression of teaching. ${ }^{44,45}$ This learning model is the right choice to improve student competence. It can be carried out during the normal learning period, and is a suitable alternative learning to increase competence during the imposition of social restrictions during the COVID-19 pandemic.

\section{CONCLUSION}

An innovative project-based learning model has successfully been developed for teaching Analytical Chemistry in tertiary institutions. Teaching materials that are equipped with the project package have met the criteria as a complete learning resource to guide students in learning the separation of analyte targets by using the Distillation method. The PjBL model is proven to be effective in guiding students to study independently as a strategy to increase knowledge and skills in the field of separation. Students successfully complete their assigned projects on time. The implementation of $\mathrm{PjBL}$ in chemistry learning is proven to be able to develop students' critical thinking skills such as the ability to organize their own projects, skills in implementing projects such as collecting, analyzing and interpreting data, and the ability to report project findings. The skills acquired by students are classified as very good $(\mathrm{M}=84.51 \pm 7.41)$. Project-based learning has motivated students to use available learning resources optimally. This learning model succeeded in improving student learning outcomes as indicated by the assessment of the project report portfolio $(\mathrm{M}=89.31 \pm 6.73)$, and from the formative test scores $(\mathrm{M}=87.18 \pm 6.33)$, all of which were classified as very good. Student competence in analytical chemistry has been achieved. The advantages possessed in project-based innovative learning are suggested to be adopted in other subjects for pharmaceutical and chemistry courses.

\section{ACKNOWLEDGEMENT}

The author acknowledges research funding given by The Directorate of Research and Community Service, Deputy for Strengthening Research and Development, Ministry of Research and Technology / National Research and Innovation Agency, in accordance with the Community Service Program Implementation Contract No 130/SP2H/LT/DRPM/2021.

\section{CONFLICT OF INTEREST}

The authors hereby declare that this research project does not have a conflict of interest.

\section{ABBREVIATIONS}

CTS: Critical thinking skill; FMIPA: Fakultas Matematika dan Ilmu Pengetahuan Alam (Faculty of Mathematics and Natural Sciences); BSNP: Badan Standar Nasional Pendidikan (Indonesian National Education Standards Board); SIPDA: Sistem Pembelajaran Daring Universitas Negeri Medan (University Online Learning System); PjBL: project-based learning.

\section{REFERENCES}

1. Persky AM, Medina MS, Castleberry AN. Developing critical thinking skills in pharmacy students. Am J Pharm Educ. 2019;83(2):7033. doi: 10.5688/ ajpe7033, PMID 30962645.

2. Cone C, Godwin D, Salazar K, Bond R, Thompson M, Myers O. Incorporation of an explicit critical-thinking curriculum to improve pharmacy students' critical-thinking skills. Am J Pharm Educ. 2016;80(3):41. doi: 10.5688/ ajpe80341, PMID 27170812.

3. Styers ML, Van Zandt PA, Hayden KL. Active learning in flipped life science courses promotes development of critical thinking skills. CBE Life Sci Educ. 2018;17(3):ar39. doi: 10.1187/cbe.16-11-0332, PMID 30040531.

4. Carson S. Targeting critical thinking skills in a first-year undergraduate Research Course. J Microbiol Biol Educ. 2015;16(2):148-56. doi: 10.1128/ jmbe.v16i2.935, PMID 26753022.

5. Juggernath A, Govender N. Natural sciences teachers' beliefs as barriers for integrating ICTs in a technology-rich context. Afr J Res Math Sci Technol Educ. 2020;24(1):105-15. doi: 10.1080/18117295.2020.1736854.

6. Sinaga M, Situmorang M, Hutabarat W. Implementation of innovative learning material to improve student's competence on chemistry. Indian J Pharm Educ Res. 2019;53(1):28-41. doi: 10.5530/ijper.53.1.5.

7. Ton TG, Gladding SP, Zunt JR, John C, Nerurkar VR, Moyer CA, et al. The development and implementation of a competency-based curriculum for training in global health research. Am J Trop Med Hyg. 2015;92(1):163-71. doi: 10.4269/ajtmh.14-0398, PMID 25371189

8. Koster A, Schalekamp T, Meijerman I. Implementation of competency-based pharmacy education (CBPE). Pharmacy (Basel). 2017;5(1):10. doi: 10.3390/ pharmacy5010010, PMID 28970422.

9. Li Y, Zhang X, Dai DY, Hu W. Curriculum innovation in times of the COVID-19 pandemic: The thinking-based instruction theory and its application. Front Psychol. 2021;12:601607. doi: 10.3389/fpsyg.2021.601607.

10. Ventura SPM, E Silva FA, Quental MV, Mondal D, Freire MG, Coutinho JAP. Ionic-liquid-mediated extraction and separation processes for bioactive compounds: Past, present, and future trends. Chem Rev. 2017;117(10):69847052. doi: 10.1021/acs.chemrev.6b00550, PMID 28151648.

11. Harris DC. Quantitative chemical analysis. 9th ed. New York: W. H. Freeman and Company; 2015.

12. Skoog DA, West DM, Holler FJ, Crouch SR. Fundamentals of analytical chemistry. 9th ed, international ed. Brooks/Cole. Cengage Learning; 2013.

13. Christian GD, Dasgupta PS, Schug K. Analytical chemistry. 7th ed. John Wiley and Sons; 2013.

14. Pandey K, Dubey RS, Prasad BB. A critical review on clinical application of separation techniques for selective recognition of uracil and 5-fluorouracil. Indian J Clin Biochem. 2016;31(1):3-12. doi: 10.1007/s12291-015-0482-4, PMID 26855482.

15. Li J, Sun D, Qian L, Liu Y. Subcritical butane extraction of wheat germoil and its deacidification by molecular distillation. Molecules. 2016;21(12):1675. doi: 10.3390/molecules21121675, PMID 27941610. 
16. Lv GP, Hu DJ, Zhou YQ, Zhang QW, Zhao J, Li SP. Preparation and application of standardized typical volatile components fraction from turmeric (Curcuma longa L.) by supercritical fluid extraction and step molecular distillation. Molecules. 2018;23(7):1831. doi: 10.3390/molecules23071831, PMID 30041445.

17. Adams $F$, Adriaens $M$. The metamorphosis of analytical chemistry. Anal Bioanal Chem. 2020;412(15):3525-37. doi: 10.1007/s00216-019-02313-z, PMID 31848669.

18. Tobiszewski M, Marć M, Gałuszka A, Namieśnik J. Green chemistry metrics with special reference to green analytical chemistry. Molecules. 2015;20(6):10928-46. doi: 10.3390/molecules200610928, PMID 26076112.

19. Jiang C, Cheng G. Problem-based learning teaching method applied to pharmaceutical engineering experiment teaching based on the outcomebased education theory. Indian J Pharm Educ Res. 2021;55(1):56-62. doi: 10.5530/ijper.55.1.8.

20. Bock A, Kniha K, Goloborodko E, Lemos M, Rittich AB, Möhlhenrich SC, et al. Effectiveness of face-to-face, blended and e-learning in teaching the application of local anaesthesia: A randomised study. BMC Med Educ. 2021;21(1):137. doi: 10.1186/s12909-021-02569-z, PMID 33639906

21. Maanvizhi S, Jaiswal JN, Narayanan RR, Rohit Jain RR. A review on virtual classroom. Indian J Pharm Educ Res. 2020;54(3s):s433-7. doi: 10.5530/ ijper.54.3s.141.

22. Morton CE, Saleh SN, Smith SF, Hemani A, Ameen A, Bennie TD, et al. Blended learning: How can we optimise undergraduate student engagement? BMC Med Educ. 2016;16:195. doi: 10.1186/s12909-016-0716-z, PMID 27492157.

23. Baser D, Ozden MY, Karaarslan H. Collaborative project-based learning: An integrative science and technological education project. Res Sci Technol Educ. 2017;35(2):131-48. doi: 10.1080/02635143.2016.1274723.

24. Kim KJ. Project-based learning approach to increase medical student empathy. Med Educ Online. 2020;25(1):1742965. doi: 10.1080/10872981.2020.1742965.

25. Si J. Course-based research experience of undergraduate medical students through project-based learning. Korean J Med Educ. 2020;32(1):47-57. doi: 10.3946/kjme.2020.152, PMID 32130850.

26. Tan JCL, Chapman A. Project-based learning for academically able student. Rotherdam, The Netherlands: Sense Publishers; 2016.

27. Sutiani A, Situmorang M, Silalahi A. Implementation of an inquiry learning model with science literacy to improve student critical thinking skills. Int $J$ Instruction. 2021;14(2):117-38. doi: 10.29333/iji.2021.1428a.

28. Rizki R, Hernando $H$, Situmorang M, Tarigan S. The development of innovative learning material with project and multimedia for redox titration. Pervasive health Pervasive Comput Technol Healthc. 2020;1:385-93.

29. Samosir RA, Bukit J, Situmorang M, Simorangkir M. Implementation of innovative learning material with project to improve student's performance in the teaching of complexometric titration. Pervasive health Pervasive Comput Technol Healthc. 2020;1:375-84.

30. Gay LR, Mills GE, Airasian PW. Educational research: Competencies for analysis and applications. USA: Pearson Education, Inc; 2011. p. $10^{\text {th }}$ ed.
31. Kimbell R, Stables K. Researching design learning: Issues and findings from two decades of research and development. Berlin: Springer; 2007.

32. Zwick M. The design, implementation, and assessment of an undergraduate Neurobiology Course using a project-based approach. J Undergrad Neurosci Educ. 2018;16(2):A131-42. PMID 30057495.

33. Tiwari R, Arya RK, Bansal M. Motivating students for project-based learning for application of research methodology skills. Int J Appl Basic Med Res. 2017;7(Suppl 1);Suppl 1 [Suppl]:S4-7. doi: 10.4103/ijabmr.IJABMR_123_17, PMID 29344449.

34. Straub J, Marsh RA, Whalen DJ. Small space craft development projectbased learning implementation and assessment of an academic program. Berlin: Springer International Publishing; 2017.

35. Juliandini G, Situmorang M, Muchtar Z. An Innovative Chemistry learning material with project and multimedia to developed students thinking skill on the teaching of anion analysis. Educ Humanit Res. 2020;488:97-103.

36. Kahlke R, Eva K. Constructing critical thinking in health professional education. Perspect Med Educ. 2018;7(3):156-65. doi: 10.1007/s40037-0180415-z, PMID 29619664.

37. $\mathrm{Pu} \mathrm{D}, \mathrm{Ni}$ J, Song $\mathrm{D}$, Zhang $\mathrm{W}$, Wang $\mathrm{Y}, \mathrm{Wu} \mathrm{L}$, et al. Influence of critical thinking disposition on the learning efficiency of problem-based learning in undergraduate medical students. BMC Med Educ. 2019;19(1):1. doi: 10.1186/ s12909-018-1418-5, PMID 30606170.

38. Laur D. Authentic learning experiences, A real-world approach to projectbased learning. New York: Eye on Education, Routledge; 2013.

39. Situmorang M, Purba J, Silaban R. Implementation of an innovative learning resource with project to facilitate active learning to improve students' performance on chemistry. Indian J Pharm Educ Res. 2020;54(4):905-14. doi: 10.5530/ijper.54.4.184.

40. Chen H, Cai D, Chen C, Wang J, Qin P, Tan T. Novel distillation process for effective and stable separation of high-concentration acetone-butanol-ethanol mixture from fermentation-pervaporation integration process. Biotechnol Biofuels. 2018;11:286. doi: 10.1186/s13068-018-1284-8, PMID 30377445.

41. Tobiszewski M. Analytical chemistry with biosolvents. Anal Bioanal Chem. 2019;411(19):4359-64. doi: 10.1007/s00216-019-01732-2, PMID 30915509.

42. Situmorang $H N$, Purba $S$, Situmorang M. Learning innovations during the pandemic COVID-19 for teaching of automotive industrial management, advances in social science, education and humanities research. 2020;488:261-7.

43. Situmorang M, Sinaga M, Purba J, Daulay SI, Simorangkir M, Sitorus M, et al. Implementation of Innovative Chemistry learning material with guided tasks to improve students' competence. J Baltic Sci Educ. 2018;17(4):535-50. doi: 10.33225/jbse/18.17.535.

44. Nainggolan B, Hutabarat W, Situmorang M, Sitorus M. Developing Innovative Chemistry laboratory workbook integrated with project-based learning and character-based chemistry. Int J Instruction. 2020;13(3):895-908. doi: 10.29333/iji.2020.13359a.

45. Purba J, Situmorang M, Silaban R. The development and implementation of innovative learning resource with guided projects for the teaching of carboxylic acid topic. Indian J Pharm Educ Res. 2019;53(4):603-12. doi: 10.5530/ijper.53.4.121.

\section{SUMMARY}

An innovative project-based learning model has been developed to facilitate students in studying Analytical Chemistry. The learning package consists of learning resources, mini projects, video examples, and worksheets that can guide students in learning the separation of target analytes by Distillation. The PjBL model is effective in guiding students to learn independently and motivating students to use learning resources optimally. The implementation of $\mathrm{PjBL}$ is proven to be able to develop students' critical thinking skills in planning, implementing, collecting data, and reporting project findings themselves. Student competence in the field of separation was achieved, student learning outcomes were classified as very good. Project-based innovative learning is very appropriate to be used for teaching pharmacy and chemistry in improving knowledge and skills, and adaptive to be applied in normal learning situations and abnormal conditions during the Covid-19 pandemic. 


\section{PICTORIAL ABSTRACT}

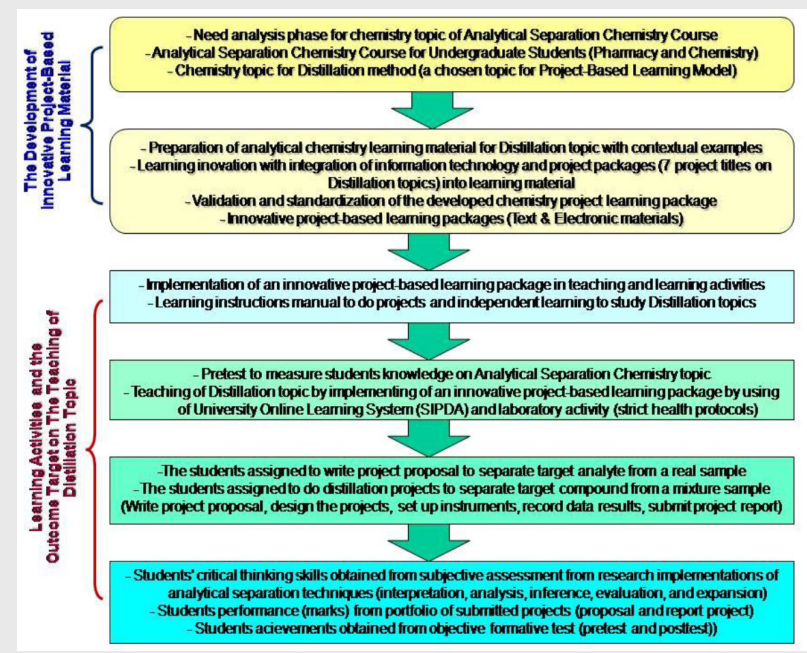

\section{About Authors}

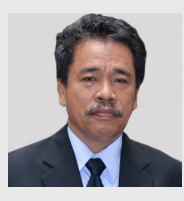

Professor Dr. Manihar Situmorang, M.Sc., was born on 4 August 1960. $\mathrm{He}$ is a Professor at Department of Chemistry, Faculty of Mathematics and Natural Sciences, Universitas Negeri Medan, Medan, North Sumatera, INDONESIA. He has been teaching for more than 35 years. He was graduated from Dept. of Chemistry Education at Institute of Teacher Training Education Medan, INDONESIA (B.Sc. 1986), and from Dept. of Chemistry, The University of New South Wales (UNSW), Australia (Grad. Diploma 1989, M.Sc, 1992 and Ph.D, 2001). He is currently a Vice Rector on Planning, Collaboration and Communication Affairs at Universitas Negeri Medan, was a Dean in Faculty of Mathematic and Natural Sciences for 8 years, and Head of Research Institute for 4 years. His research interests are Sensor Development, Electroanalysis, Environmental Study and Chemistry Education.

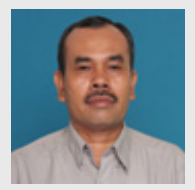

Dr. Marudut Sinaga, MS. was born on 16 Februari 1963. He is a lecturer at Chemistry Education, Graduate Study Program, Universitas Negeri Medan, Medan, North Sumatera, INDONESIA. He was graduated from Dept. of Chemistry Education at Institute of Teacher Training Education Medan,INDONESIA (B.Sc. 1987), Dept. of Chemistry, Universitas Gajah Mada (M.Sc. 1996), and Doctor in Chemistry (Ph.D, 2021) from Universitas Negeri Medan. He has been teaching for more than 25 years. His research interests are on Analytical Chemistry and Chemistry Education.

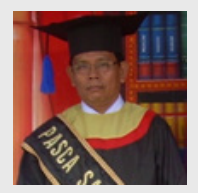

Dr. Marham Sitorus, MS., was born on 1 January 1963. He is a senior lecturer at Department of Chemistry, Faculty of Mathematics and Natural Science (FMIPA), Universitas Negeri Medan, Medan, North Sumatera, INDONESIA. He was graduated from Dept. of Chemistry at Universitas Gajah Mada (UGM), (B.Sc. 1987), Master in Chemistry (M.Sc, 1995, UGM) and Doctor in Chemistry (Ph.D, 2010) from Universitas Andalas (UNAND), INDONESIA. He hold a position as Head of Chemistry FMIPA, Universitas Negeri Medan (2011- 2016). He has been teaching for more than 31 years. His research interests are on Organic Synthesis, Organic Analysis, and Chemistry Education.

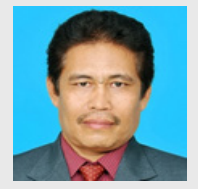

Dr. Ajat Sudrajat, MS, was born on 25 June 1964. He is a senior lecturer at Chemistry Education, Graduate Study Program, Universitas Negeri Medan, Medan, North Sumatera, INDONESIA. He has been teaching for more than 31 years. He was graduated from Dept. of Chemistry Education at Universitas Pendidikan Indonesia (UPI) Bandung, INDONESIA (B.Sc. 1990), Master in Chemistry from Dept. of Chemistry Institut Teknologi Bandung (ITB) (M.Sc, 1996) and Doctor in Chemistry Education (Ph.D, 2013) from UPI, Bandung, INDONESIA. He hold a position as Secretary of Education, Graduate Study Program (2015 - now). His research interests are on Analytical Chemistry and Chemistry Education.

Cite this article: Situmorang M, Sinaga M, Sitorus M, Sudrajat A. Implementation of Project-based Learning Innovation to Develop Students' Critical Thinking Skills as a Strategy to Achieve Analytical Chemistry Competencies. Indian $\mathrm{J}$ of Pharmaceutical Education and Research. 2022;56(1s):s41-s51. 